\title{
Effects of omega-3 and -6 polyunsaturated fatty acids on ovine follicular cell steroidogenesis, embryo development and molecular markers of fatty acid metabolism
}

\author{
Jaime Hughes ${ }^{1,2}$, Wing Yee Kwong ${ }^{1}$, Dongfang $\mathrm{Li}^{1}$, Andrew M Salter ${ }^{1}$, Richard G Lea ${ }^{2}$ \\ and Kevin D Sinclair ${ }^{1}$ \\ ${ }^{1}$ Schools of Biosciences and ${ }^{2}$ Veterinary Medicine and Science, University of Nottingham, Sutton Bonington Campus, \\ Leicestershire LE12 5RD, UK
}

Correspondence should be addressed to KD Sinclair; Email: kevin.sinclair@nottingham.ac.uk

\begin{abstract}
We previously reported increased follicular fluid progesterone $\left(P_{4}\right)$ concentrations in ewes fed an n-3 compared to an n-6 polyunsaturated fatty acid (PUFA)-enriched diet, but detected no differential effect of n-3 and n-6 PUFA-enriched high-density lipoproteins (HDL) on granulosa cell (GC) steroidogenesis in vitro. Moreover, net n-6 PUFA-enriched HDL reduced early embryo development, but in the absence of a net uptake of FA. Consequently, we hypothesised that a) effects of $n-3$ PUFA on ovarian steroidogenesis are mediated by theca rather than GCs and b) during embryo culture lipids are acquired solely from the albumin fraction of serum, so that albumin-delivered n-3 and n-6 PUFA exert a greater differential effect on embryo development than either low-density lipoprotein (LDL)- or HDL-delivered PUFA. Data confirmed that $n-3$ PUFA increases $\mathrm{P}_{4}$ production solely in theca cells and that this is associated with an increase in STAR transcript expression. Furthermore, LDL- and HDL-delivered n-3 PUFA are equally efficacious in this regard during the first $96 \mathrm{~h}$ of culture, but thereafter only HDL-delivered n-3 PUFA induces this effect in partially luteinised theca cells. We also demonstrate that albumin is the sole serum fraction that leads to a net uptake of FA during embryo culture. PUFA-enriched serum and albumin increased the yield of morphologically poorer quality blastocysts with increased transcript expression for the antioxidant enzyme SOD1. Important differential effects of n-3 and n-6 PUFA on ovarian steroidogenesis acting solely on theca cells are identified, but differential effects of PUFA on embryo development are less apparent.

Reproduction (2011) 141 105-118
\end{abstract}

\section{Introduction}

Polyunsaturated fatty acids (PUFAs) are known to exert a broad range of effects on reproductive tissues (Wathes et al. 2007) although the benefits to fertility from feeding PUFA-enriched diets, particularly to lactating ruminants, have been inconsistent (Santos et al. 2008). In part, this may be due to modifications that occur to PUFA in the rumen of cattle and sheep. These modifications include a reduction in the number of double bonds and isomer reorientation leading to an increase in the production of saturated and monounsaturated FA (MUFA), as well as polyunsaturated trans-FA most notably vaccenic acid (C18:1 trans-11; Jenkins 1994). Long-chain PUFAs are, however, less affected by these processes and we (e.g. Fouladi-Nashta et al. 2009) and others (e.g. Childs et al. 2008) have successfully altered the PUFA composition of various tissues and biological fluids in lactating and non-lactating ruminants by feeding a variety of PUFArich plant and animal oils. We have also observed that saturated FAs are preferentially accumulated by the follicle-enclosed oocyte, suggesting selective uptake mechanisms or de novo synthesis that favours this class of FA (Adamiak et al. 2006). As a consequence of this, and possibly because we used vegetable sources of PUFA, we have been unable to alter the FA composition of granulosa cells (GCs) and oocytes in lactating dairy cows (Fouladi-Nashta et al. 2009). In contrast, a combination of vegetable and fish oils in diets of nonlactating sheep significantly altered the PUFA composition of both GCs and oocytes (Wonnacott et al. 2010).

The feeding of $n-3$ relative to $n-6$ PUFA-enriched diets in that latter study also increased follicular fluid progesterone $\left(\mathrm{P}_{4}\right)$ concentrations, but we were unable to reproduce this effect in GCs cultured in the presence of n-3 and n-6 PUFA-enriched high-density lipoproteins (HDL) fractionated from the sera of these ewes. This led to the hypothesis that the differential effects of $n-3$ and n-6 PUFA on ovarian steroidogenesis may be mediated by theca rather than GCs. There was also no net uptake of FA by sheep embryos cultured in the presence of PUFA-enriched HDL in that study, although PUFA 
supplementation altered the expression of transcripts for scavenger receptor class B member 1 (SCARB1), low-density lipoprotein receptor $(L D L R)$ and stearoyl$C o A$ desaturase $(S C D)$, indicating that embryos were responsive to the presence of PUFA-enriched HDL in culture. Indeed, n-6 PUFA-enriched HDL reduced the proportion of zygotes that developed to the blastocyst stage, although the mechanisms that underly this effect remain elusive.

The purpose of the current series of experiments, therefore, was to extend these observations to firstly investigate the differential effects of $n-3$ and n-6 PUFAenriched HDL and LDL on granulosa- and theca-cell development and steroidogenesis during culture. Sheep zygotes were also cultured to the blastocyst stage in the presence of $n-3$ and n- 6 PUFA-enriched LDL, albumin or serum. The purpose was to test the hypothesis that serum-derived lipids (Thompson et al. 1995) are delivered only by the albumin fraction of serum, so that we may expect albumin-delivered n-3 and $n-6$ PUFA to exert a greater differential effect on pre-implantation embryo development than either the LDL- or the HDL-delivered n-3 and n-6 PUFA tested by Wonnacott et al. (2010). Given the differences in PUFA content of GCs and embryos reported by Wonnacott et al. (2010), and the differences in PUFA composition anticipated in the current series of experiments, a further object of this study is to determine transcript expression for a number of enzymes involved in fatty acid elongation (i.e. ELOVL2 and ELOVL5) and desaturation (i.e. SCD, FADS1 and FADS2), together with enzymes associated with follicular cell steroidogenesis (STAR, CYP11A1, CYP17A1 and HSD3B1) and cellular stress (SOD1). ELOVL2 and ELOVL5 are involved in the conversion of the essential FA precursors linoleic $(\mathrm{C} 18: 2 \mathrm{n}-6)$ and $\alpha$-linolenic (C18:3n-3) acids to arachidonic acid (C20:4n-6) and docosahexaenoic acid (DHA; C22:6n-3) (Guillou et al. 2010), and the majority of Elovl5 ${ }^{-1-}$ female mice are infertile (Moon et al. 2009). The $\Delta 6$-desaturase FADS2 is the sole enzyme that catalyses the initial, ratelimiting desaturation of linoleic (C18:2n-6) and $\alpha$-linolenic $(C 18: 3 n-3)$ acids for the production of longer chain PUFA. Biological fluids and tissues (including ovaries and testes) of Fads $2^{-1-}$ mice are devoid of PUFA and, while male and female Fads $2^{-1-}$ mice are viable and have a normal lifespan, they too are sterile (Stoffel et al. 2008). As the feeding of fish oils to rats inhibits de novo lipogenesis and expression of all fatty acid desaturases and specific (i.e. ELOVL5 but not ELOVL2) elongases in primary hepatocytes (Wang et al. 2005), we sought to determine what differential effect n-3 and n-6 PUFA-enriched lipoproteins would have on transcript expression for these enzymes in cultured ovarian follicular cells and preimplantation embryos.

\section{Results}

A detailed breakdown of the FA composition of serum, $\mathrm{LDL}, \mathrm{HDL}$ and albumin fractions used for cell and embryo culture in this study is provided in Table 1, and the composition of basal media can be found online (Supplementary Table 5, see section on supplementary data given at the end of this article). Maternal dietary treatment was effective in significantly altering the relative proportions of $n-3$ and $n-6$ PUFA in serum and each of the three serum fractions (Table 1; Supplementary Tables $1-4$, see section on supplementary data given at the end of this article). Of further note, in Supplementary Table 5, the trace amounts of FA were detected in basal media, the inclusion of FA-free (FAF) BSA in synthetic oviductal fluid medium (SOFM) did not increase these further, and the measured total amount of FA in DMEM with added n-6 PUFA-enriched HDL $(73.0 \mu \mathrm{g} / \mathrm{ml})$ matched the calculated concentration $(72.3 \mu \mathrm{g} / \mathrm{ml})$ based on the composition of serum at an intended $5 \% \mathrm{v} / \mathrm{v}$ incorporation rate (Table 1 ).

Table 1 Fatty acid (FA) composition of (a) serum, (b) low-density lipoprotein (LDL), (c) high-density lipoprotein (HDL) and (d) albumin fractionated from the serum that was derived from ewes offered diets differing in n-3 and n- 6 polyunsaturated FA (PUFA; Wonnacott et al. 2010). Analyses were based on two replicate batches.

\begin{tabular}{|c|c|c|c|c|}
\hline \multirow[b]{2}{*}{ Dietary treatment } & \multicolumn{2}{|c|}{$\mathrm{g} / 100 \mathrm{~g}$ total FA } & \multirow[b]{2}{*}{ S.E.D. } & \multirow[b]{2}{*}{$\boldsymbol{P}$} \\
\hline & $n-3$ & $n-6$ & & \\
\hline (a) Serum TFA $(\mu \mathrm{g} / \mathrm{ml})$ & 1439 & 1445 & & \\
\hline Saturated & 36.51 & 36.50 & 0.189 & - \\
\hline Unsaturated & 59.08 & 59.13 & 0.718 & - \\
\hline MUFA & 17.29 & 18.72 & 0.618 & - \\
\hline PUFA & 41.79 & 40.41 & 0.544 & - \\
\hline n-6 series & 23.51 & 36.62 & 0.432 & $<0.001$ \\
\hline $\mathrm{n}-3$ series & 18.28 & 3.79 & 0.133 & $<0.001$ \\
\hline Ratio of n-6:n-3 & 1.29 & 9.66 & 0.234 & $<0.001$ \\
\hline (b) LDL TFA ( $\mu \mathrm{g} / \mathrm{ml})$ & 1519 & 1012 & & \\
\hline Saturated & 36.8 & 41.5 & 0.192 & 0.002 \\
\hline Unsaturated & 58.8 & 53.9 & 0.624 & 0.015 \\
\hline MUFA & 19.5 & 20.7 & 0.598 & - \\
\hline PUFA & 39.3 & 33.1 & 0.149 & $<0.001$ \\
\hline$n-6$ series & 24.7 & 30.5 & 0.124 & $<0.001$ \\
\hline $\mathrm{n}-3$ series & 14.6 & 2.63 & 0.045 & $<0.001$ \\
\hline Ratio of n-6:n-3 & 1.68 & 11.6 & 0.020 & $<0.001$ \\
\hline (c) HDL TFA $(\mu \mathrm{g} / \mathrm{ml})$ & 3321 & 3171 & & \\
\hline Saturated & 33.9 & 30.2 & 0.612 & 0.026 \\
\hline Unsaturated & 61.6 & 64.9 & 0.521 & 0.024 \\
\hline MUFA & 18.2 & 20.1 & 0.796 & - \\
\hline PUFA & 43.5 & 44.8 & 0.276 & 0.039 \\
\hline n-6 series & 27.7 & 41.5 & 0.267 & $<0.001$ \\
\hline $\mathrm{n}-3$ series & 15.7 & 3.30 & 0.085 & $<0.001$ \\
\hline Ratio of n-6:n-3 & 1.76 & 12.5 & 0.034 & $<0.001$ \\
\hline (d) Albumin TFA $(\mu \mathrm{g} / \mathrm{ml})$ & 88.6 & 89.6 & & \\
\hline Saturated & 38.9 & 44.0 & 0.261 & 0.003 \\
\hline Unsaturated & 57.1 & 51.4 & 0.258 & 0.002 \\
\hline MUFA & 20.8 & 20.8 & 0.576 & - \\
\hline PUFA & 36.3 & 30.6 & 0.754 & 0.017 \\
\hline n-6 series & 16.7 & 25.7 & 0.298 & $<0.001$ \\
\hline $\mathrm{n}-3$ series & 19.6 & 4.91 & 0.460 & $<0.001$ \\
\hline Ratio of $n-6: n-3$ & 0.85 & 5.24 & 0.073 & $<0.001$ \\
\hline
\end{tabular}




\section{Granulosa cell culture}

The total FA content (TFA, $\mu \mathrm{g} / 10^{5}$ cells) of GCs following $144 \mathrm{~h}$ culture did not differ between lipoprotein fractions or between dietary sources of PUFA (Table 2). The percentage MUFA, however, was lower $(P=0.04)$ whereas the percentage PUFA was higher $(P=0.004)$ in GCs cultured in the presence of HDL than LDL; n-6enriched LDL and HDL increased $(P=0.014)$ n- 6 series PUFA in GCs relative to $\mathrm{n}-3$ series PUFA. Conversely, $\mathrm{n}$-3-enriched $\mathrm{LDL}$ and $\mathrm{HDL}$ increased $(P=0.04) \mathrm{n}-3$ series PUFA in GCs relative to $n-6$ series PUFA. The most abundant FA in GCs was oleic acid (C18:1n-9), comprising on average $30.9 \pm 0.35 \mathrm{~g} / 100 \mathrm{~g}$ of TFA (Supplementary Table 6, see section on supplementary data given at the end of this article). Its content was greater $(P<0.05)$ in LDL and $\mathrm{n}-6$ than HDL and $\mathrm{n}-3-$ cultured cells. The second most abundant FA was palmitic acid (C16:0), comprising 23.2 $\pm 0.18 \mathrm{~g} / 100 \mathrm{~g}$ TFA, and stearic acid (C18:0) was the third (11.5 $\pm 0.66 \mathrm{~g} / 110 \mathrm{~g}$ TFA). Of the seven n-6 PUFA identified, three were increased in cells cultured with $n-6$, regardless of lipoprotein fraction: linoleic $(C 18: 2 n-6)$ $(P<0.001), \gamma$-linolenic $(C 18: 3 n-6)(P=0.02)$ and eicosadienoic (C20:2n-6) $(P=0.02)$. Similarly, of the five $\mathrm{n}-3$ PUFA identified, four were increased in cells cultured with n-3 PUFA: $\alpha$-linolenic acid (C18:3n-3) $(P=0.002)$, eicosapentaenoic acid (C20:5n-3) $(P<0.001)$, docosapentaenoic acid $(\mathrm{C} 22: 5 \mathrm{n}-3)(P=0.003)$ and DHA $(\mathrm{C} 22: 6 n-3)(P=0.02)$.

There was no differential effect of lipoprotein fraction or dietary source of PUFA on cell proliferation or steroid production by GCs (Table 3). Cell number increased $(P<0.001)$ between 48 and $96 \mathrm{~h}$ of culture, but decreased between 96 and 144 h. Cell-number-adjusted oestradiol $\left(E_{2}\right)$ concentrations in spent media decreased $(P<0.001)$ with time during culture while $\mathrm{P}_{4}$ concentrations increased $(P<0.001)$.

Transcripts for CYP17A and ELOVL2 were not expressed in GCs. All other transcripts were expressed. The following transcripts, however, were not affected by lipoprotein fraction or dietary PUFA source: $S C D$, FADS1, FADS2, HSD3B1, SCARB1, LDLR, ELOVL5 and CYP11A1. The latter four transcripts were also not affected by duration of culture and so data are not presented. Transcript expression for $S C D$ increased $(P<0.001)$ by 7.5 -fold between 48 and $144 \mathrm{~h}$ of culture. Transcript expression for FADS1 and FADS2 generally increased $(P<0.001)$ during culture, although transcripts for the latter gene were barely detectable. In contrast, transcript expression for HSD3B1 decreased $(P<0.001)$ between 48 and $96 \mathrm{~h}$ of culture before increasing again by $144 \mathrm{~h}$. STAR expression was greater $(P=0.018)$ in GCs cultured in the presence of LDL than HDL and increased $(P<0.001)$ with time during culture by more than fourfold.

\section{Theca cell culture}

The TFA content (TFA, $\mu \mathrm{g} / 10^{5}$ cells) of theca cells following $144 \mathrm{~h}$ culture did not differ between lipoprotein fractions or between dietary sources of PUFA, although it was lower for cells cultured with n-3 PUFA LDL than those with n-6 PUFA LDL $(P=0.04$; Table 2). Similarly, the percentage MUFA was greatest $(P=0.004)$ for cells cultured with n-6 PUFA LDL and least for cells cultured with n-3 PUFA LDL. In keeping with GCs, n-6enriched LDL and HDL increased $(P<0.001) \mathrm{n}-6$ series PUFA relative to $n-3$ series PUFA, while $n$-3-enriched

Table 2 Effect of culture treatment (lipoprotein fraction and dietary source of polyunsaturated fatty acid (PUFA)) on total FA (TFA) and percentage (g/100 g TFA) of saturated FA, unsaturated FA, monounsaturated FA (MUFA) and PUFA in (a) granulosa and (b) theca cells following culture for $144 \mathrm{~h}$.

\begin{tabular}{|c|c|c|c|c|c|c|c|c|}
\hline \multirow{2}{*}{$\begin{array}{l}\text { Lipoprotein (L) } \\
\text { Dietary source (D) }\end{array}$} & \multicolumn{2}{|c|}{ LDL } & \multicolumn{2}{|c|}{ HDL } & \multirow[b]{2}{*}{ S.E.D. } & \multicolumn{3}{|c|}{ Significance } \\
\hline & $n-3$ & $n-6$ & $n-3$ & $n-6$ & & L & $\mathrm{D}$ & $L \times D$ \\
\hline \multicolumn{9}{|l|}{ (a) Granulosa cells } \\
\hline$n$ & 6 & 6 & 6 & 6 & & & & \\
\hline TFA $\left(\mu \mathrm{g} / 10^{5}\right.$ cells $)$ & 5.55 & 6.50 & 6.11 & 6.04 & 0.70 & - & - & - \\
\hline Saturated & 40.2 & 38.0 & 39.1 & 38.8 & 0.71 & - & - & - \\
\hline Unsaturated & 54.0 & 56.2 & 55.2 & 55.6 & 0.76 & - & - & - \\
\hline MUFA & 36.1 & 38.0 & 35.6 & 35.9 & 0.55 & 0.04 & - & - \\
\hline PUFA & 17.9 & 18.2 & 19.6 & 19.6 & 0.41 & 0.004 & - & - \\
\hline$n-6$ series & 10.4 & 12.3 & 10.8 & 13.4 & 0.73 & - & 0.014 & - \\
\hline n-3 series & 7.51 & 5.95 & 8.82 & 6.22 & 0.86 & - & 0.04 & - \\
\hline Ratio of n-6:n-3 & 1.44 & 2.24 & 1.25 & 2.23 & 0.30 & - & 0.02 & - \\
\hline \multicolumn{9}{|l|}{ (b) Theca cells } \\
\hline$n$ & 6 & 6 & 6 & 6 & & & & \\
\hline TFA ( $\mu \mathrm{g} / 10^{5}$ cells $)$ & 3.62 & 4.76 & 4.33 & 4.14 & 0.42 & - & - & 0.04 \\
\hline Saturated & 38.6 & 35.3 & 35.9 & 36.9 & 1.12 & - & - & - \\
\hline Unsaturated & 55.6 & 58.8 & 58.3 & 57.3 & 1.06 & - & - & - \\
\hline MUFA & 32.6 & 37.2 & 34.7 & 35.5 & 0.77 & - & $<0.001$ & 0.004 \\
\hline PUFA & 22.9 & 21.7 & 23.6 & 21.8 & 0.89 & - & - & - \\
\hline$n-6$ series & 11.7 & 15.8 & 12.2 & 16.1 & 0.44 & - & $<0.001$ & - \\
\hline$n-3$ series & 11.3 & 5.80 & 11.4 & 5.71 & 0.50 & - & $<0.001$ & - \\
\hline Ratio of n-6:n-3 & 1.03 & 2.74 & 1.07 & 2.84 & 0.08 & - & $<0.001$ & - \\
\hline
\end{tabular}


Table 3 Effect of culture treatment (lipoprotein fraction and dietary source of polyunsaturated fatty acid (PUFA)) and culture duration on granulosa cell proliferation, oestradiol $\left(\mathrm{E}_{2}\right)$ and progesterone $\left(\mathrm{P}_{4}\right)$ production (both adjusted for cell number) and transcript expression.

\begin{tabular}{|c|c|c|c|c|c|c|c|c|c|c|c|c|}
\hline \multirow{2}{*}{$\begin{array}{l}{\text { Lipoprotein }(\mathrm{L})^{\mathrm{a}}} \\
\text { Dietary source (D) }\end{array}$} & \multicolumn{2}{|c|}{ LDL } & \multicolumn{2}{|c|}{ HDL } & \multirow[b]{2}{*}{ S.E.D. } & \multicolumn{3}{|c|}{ Time of culture $(\mathrm{h})(\mathrm{T})$} & \multirow[b]{2}{*}{ S.E.D. } & \multicolumn{3}{|c|}{ Significance } \\
\hline & $n-3$ & $n-6$ & $n-3$ & $n-6$ & & 48 & 96 & 144 & & L & $\mathrm{D}$ & $\mathrm{T}$ \\
\hline \multicolumn{13}{|c|}{ Cell proliferation and steroidogenesis } \\
\hline$n$ & 36 & 36 & 36 & 36 & & 48 & 48 & 48 & & & & \\
\hline Cell number $\left(\times 10^{5}\right)$ & 2.93 & 3.00 & 3.18 & 3.02 & 0.152 & 2.81 & 3.41 & 2.86 & 0.132 & - & - & $<0.001$ \\
\hline $\mathrm{E}_{2}\left(\mathrm{pg} / 10^{5}\right.$ cells) & 1289 & 1276 & 1259 & 1186 & 77.1 & 2337 & 847 & 566 & 66.8 & - & - & $<0.001$ \\
\hline $\mathrm{P}_{4}\left(\mathrm{pg} / 10^{5}\right.$ cells $)$ & 345 & 281 & 256 & 232 & & & 442 & 959 & & & & \\
\hline$\left(\log _{10}\right)$ & $(2.538)$ & $(2.450)$ & $(2.408)$ & $(2.366)$ & $(0.0577)$ & (1.694) & $(2.645)$ & $(2.982)$ & $(0.0499)$ & 0.012 & - & $<0.001$ \\
\hline \multicolumn{13}{|c|}{ Transcript expression relative to $A C T B$} \\
\hline$n$ & 9 & 9 & 9 & 9 & & 12 & 12 & 12 & & & & \\
\hline SCD & 0.0753 & 0.0704 & 0.0734 & 0.0925 & 0.0080 & 0.0197 & 0.0666 & 0.1475 & 0.0070 & - & - & $<0.001$ \\
\hline FADS1 & 0.0036 & 0.0030 & 0.0034 & 0.0038 & 0.0008 & 0.0024 & 0.0024 & 0.0056 & 0.0007 & - & - & $<0.002$ \\
\hline FADS2 & 0.0007 & 0.0008 & 0.0008 & 0.0007 & 0.0001 & 0.0005 & 0.0010 & 0.0007 & 0.0001 & - & - & $<0.001$ \\
\hline HSD3B1 & 0.0731 & 0.0677 & 0.0667 & 0.0782 & 0.0090 & 0.0796 & 0.0405 & 0.0941 & 0.0080 & - & - & $<0.001$ \\
\hline STAR & 0.0049 & 0.0044 & 0.0033 & 0.0033 & 0.0007 & 0.0015 & 0.0033 & 0.0069 & 0.0006 & 0.018 & - & $<0.001$ \\
\hline
\end{tabular}

${ }^{\mathrm{a}}$ Data averaged over the three time points (i.e. 48,96 and $144 \mathrm{~h}$ culture).

LDL and HDL increased $(P<0.001)$ n-3 series PUFA relative to $n-6$ series PUFA, in theca cells. As for GCs, the most abundant FA was oleic acid (C18:1n-9c), comprising on average $31 \pm 0.35 \mathrm{~g} / 100 \mathrm{~g}$ of TFA (Supplementary Table 7 , see section on supplementary data given at the end of this article). Its content was greatest $(P<0.001)$ in cells cultured with n-6 PUFA. The second most abundant FA was palmitic acid (C16:0), comprising 21.2 \pm 0.52 $\mathrm{g} / 100 \mathrm{~g}$ TFA, and stearic acid (C18:0) was the third $(12.35 \pm 0.26 \mathrm{~g} / 110 \mathrm{~g}$ TFA). Of the seven $\mathrm{n}-6$ FA identified, four were increased in cells cultured with n-6 PUFA: linoleic (C18:2n-6) $(P<0.001)$, eicosadienoic $(\mathrm{C} 20: 2 \mathrm{n}-6) \quad(P=0.002)$, dihomo- $\gamma$-linolenic acid $(\mathrm{C} 20: 3 n-6)(P=0.009)$ and arachidonic acid $(P<0.001)$. Similarly, all five identified n-3 FA were increased $(P<0.001)$ in cells cultured with n-3 PUFA. Lipoproteins did not have an effect on FA uptake in these cells.

Similar to GCs, there was no overall (i.e. across all time points) differential effect of lipoprotein fraction or dietary source of PUFA on theca cell proliferation (Table 4). Cell number increased $(P<0.001)$ with time during culture, and there was evidence $(P=0.012)$ of a lipoprotein fraction $\times$ culture time interaction. Cell number $\left(\times 10^{5}\right)$ increased with time $(48,96$ and $144 \mathrm{~h})$ in the presence of both HDL (1.79, 2.26 and 2.85; S.E.D. $=0.128)$ and $\operatorname{LDL}(1.61,2.47$ and 3.22; S.E.D. $=0.128)$ but the fold increase in number was greater for cells cultured in the presence of the latter lipoprotein fraction. Cell-number-adjusted $E_{2}$ concentrations in spent media were extremely low at all time points during culture and were neither affected by lipoprotein fraction nor dietary source of PUFA. In contrast, cell-number-adjusted $\mathrm{P}_{4}$ concentrations in spent media increased $(P<0.001)$ with time during culture and were greater $(P<0.001)$ across all time points for cells cultured in the presence of $n-3$ PUFA than n-6 PUFA irrespective of lipoprotein source. However, when data for $144 \mathrm{~h}$ were analysed separately, there was evidence $(P=0.037)$ of a lipoprotein fraction $\times$ dietary PUFA source interaction, which indicated that $\mathrm{P}_{4}$ production was greatest for cells cultured in the presence of $\mathrm{n}-3 \mathrm{HDL}$ than for the other treatment combinations (geometric means for $\mathrm{n}-3 \mathrm{HDL}$, n-6 HDL, n-3 LDL and n-6 LDL of 1387, 592, 653 and $705 \mathrm{ng} / 10^{5}$ cells respectively).

As for GCs, transcripts for ELOVL2 were not expressed in theca cells. Although transcripts for $L D L R$ and FADS2 were expressed in theca cells, they were not affected by culture treatment or duration of culture and so these data are not presented. The expression of all remaining transcripts was altered $(P<0.001)$ during culture (Table 4). For most of these transcripts, expression increased with time during culture. The most dramatic increases in expression were for the two steroidogenic enzymes STAR (sixfold increase) and HSD3B1 (eightfold increase). In contrast, CYP17A1 transcript expression decreased with time during culture so that, by $144 \mathrm{~h}$ culture, levels were around $8 \%$ of those at $48 \mathrm{~h}$. There was an interaction $(P=0.008)$ between lipoprotein fraction and PUFA source with respect to SCARB1 expression. Transcript expression was greater for $n-3$ LDL and n-6 HDL than for n-6 LDL and n-3 HDL. Transcript expression for ELOVL5 was also greater $(P=0.018)$ for $\mathrm{n}-3 \mathrm{LDL}$ than for the other treatment combinations. The only clear-cut effect of dietary PUFA source, however, was for STAR expression; n-3 PUFA increased $(P=0.006)$ STAR transcript expression relative to $n-6$ PUFA irrespective of lipoprotein fraction.

\section{Embryo culture}

Experiments were conducted with sheep embryos, which involved culturing two- to four-cell zygotes to the blastocyst stage in SOFM with one of three PUFA-enriched supplements added: a) serum, b) LDL or c) albumin (Table 1). Both LDL and albumin were fractionated from the serum used in this study, which in 


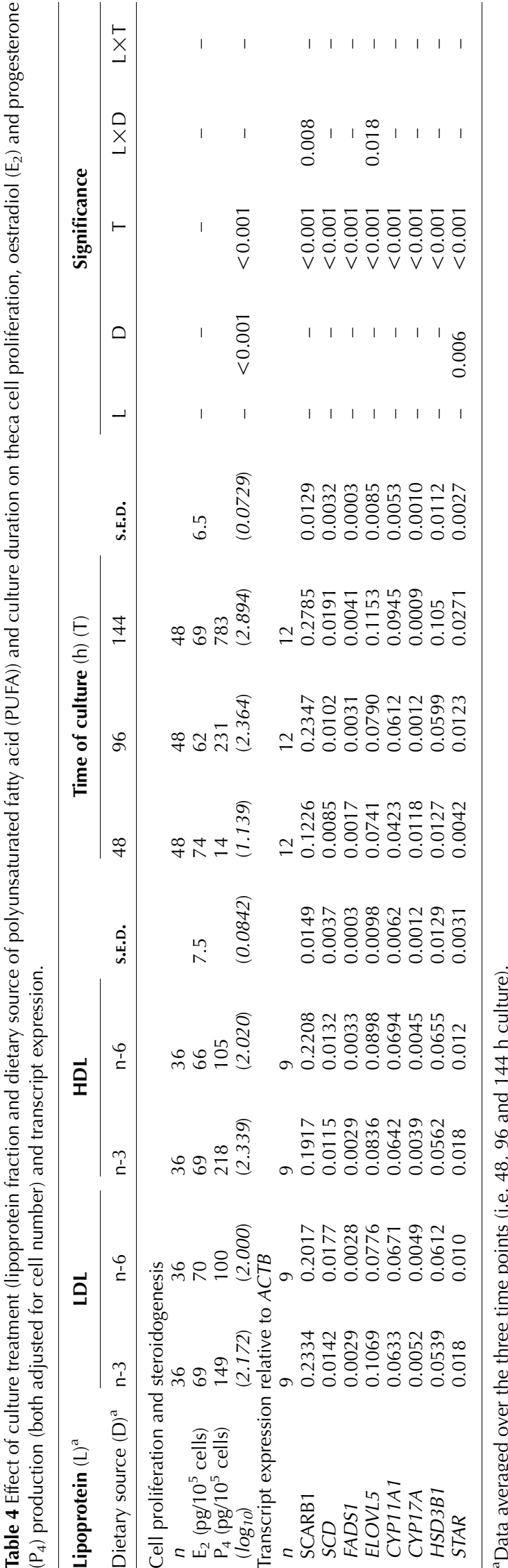

turn was derived from the ewes that were offered $n-3$ or n-6 PUFA-enriched diets, as described earlier.

An orthogonal contrast analysis indicated that the inclusion of PUFA-enriched serum in SOFM increased $(P=0.036)$ the FA content (ng/blastocyst) of Day-7 blastocysts relative to the embryos cultured with FAFBSA (Table 5). The inclusion of serum also increased the percentage and absolute mass (ng/blastocyst) of $n-3$ PUFA but not of $n-6$ PUFA. Furthermore, relative to $n-6$ PUFA-enriched serum, n-3 PUFA-enriched serum increased the percentage n-3 PUFA and reduced the ratio of n-6:n-3 PUFA in blastocysts; n-3 PUFA-enriched serum was also effective in increasing $(P=0.004)$ the percentage and absolute mass of eicosapentaenoic acid (C22:5n-3) and DHA (C22:6n-3) in Day-7 blastocysts (Supplementary Table 8 , see section on supplementary data given at the end of this article).

Similar to serum, the inclusion of PUFA-enriched albumin in SOFM increased $(P=0.02)$ the FA content of Day-7 blastocysts relative to embryos cultured with LDL and FAF-BSA (Table 6). Relative to n-6 PUFA-enriched albumin, the inclusion of $n-3$ PUFA-enriched albumin increased $(P=0.042)$ the percentage n-3 PUFA and reduced $(P=0.047)$ the ratio of $\mathrm{n}-6: \mathrm{n}-3$ PUFA in blastocysts. As for serum, notable PUFA increases in blastocysts by n-3 PUFA-enriched albumin were eicosapentaenoic acid (C22:5n-3) and DHA (C22:6n-3) (Supplementary Table 9, see section on supplementary data given at the end of this article).

There were marked differences between the embryo culture experiments described above in the relative percentages of the different FA classes, which could not be ascribed to the nature and composition of the supplements used. Blastocysts from the serum experiment had the greatest percentage saturated FA (56.6 $\pm 2.1 \%)$ consisting mostly stearic acid (C18:0, 30.5 $\pm 1.3 \%$ ) and palmitic acid (C16:0, 22.8 $\pm 0.8 \%)$. The next mostly abundant FA was oleic acid (C18:1n-9, 29.1 $\pm 1.5 \%)$ followed by linoleic acid (C18:2n-6, 4.03 $\pm 0.06 \%$ ). In contrast, embryos cultured in the presence of either LDL or albumin had the greatest percentage MUFA ( $48.7 \pm 0.6 \%)$, where once again oleic acid (C18:1 n-9, 46.0 $\pm 0.5 \%$ ) was the most abundant FA. Stearic acid (C18:0, 14.9 $\pm 0.3 \%$ ) was the next most abundant FA, followed by palmitic acid (C16:0, 13.6 $\pm 0.2 \%)$ and then linoleic acid (C18:2n-6, 7.00 $\pm 0.17 \%)$.

In a separate series of experiments, the inclusion of PUFA-enriched serum and albumin increased the proportion of blastocysts present on Days $6(P<0.001)$ and $7(P<0.05)$ of culture relative to the FAF-BSA control (Fig. $1 \mathrm{~A}$ and $\mathrm{C}$ ). In contrast, the inclusion of PUFAenriched LDL had no effect on embryo development (Fig. 1B). There was no differential effect of dietary source of PUFA on the percentage of zygotes that developed to the blastocyst stage. Similarly, there was no effect of PUFA source nor indeed supplement type on the proportion of blastocysts classified (according to IETS 
Table 5 Total fatty acids (TFA) and percentages (g/100 g TFA) of saturated FA, unsaturated FA, monounsaturated FA (MUFA) and polyunsaturated FA (PUFA) of Day-7 sheep blastocysts cultured ${ }^{\mathrm{a}}$ in vitro.

\begin{tabular}{|c|c|c|c|c|c|c|}
\hline \multirow{2}{*}{$\begin{array}{l}\text { Culture treatment } \\
\text { PUFA source }\end{array}$} & \multirow[b]{2}{*}{ FAF-BSA } & \multicolumn{2}{|c|}{ Serum } & \multirow[b]{2}{*}{ S.E.D. } & \multicolumn{2}{|c|}{ Orthogonal contrasts } \\
\hline & & $n-3$ & $n-6$ & & BSA versus serum & $n-3$ versus $n-6$ \\
\hline$n$ & 4 & 4 & 4 & & & \\
\hline TFA (ng/blastocyst) & 150.6 & 157.8 & 166.6 & 4.97 & 0.036 & - \\
\hline Saturated & 55.5 & 56.2 & 58.0 & 1.01 & - & - \\
\hline Unsaturated & 40.7 & 40.2 & 38.3 & 0.94 & - & - \\
\hline MUFA & 32.6 & 31.8 & 30.8 & 0.60 & 0.05 & - \\
\hline PUFA & 8.1 & 8.3 & 7.5 & 0.41 & - & - \\
\hline$n-6$ series & 7.2 & 6.1 & 6.0 & 0.28 & 0.004 & - \\
\hline$n-3$ series & 0.9 & 2.2 & 1.5 & 0.16 & $<0.001$ & 0.004 \\
\hline Ratio of n-6:n-3 & 7.7 & 2.7 & 4.2 & 0.49 & $<0.001$ & 0.002 \\
\hline
\end{tabular}

${ }^{a}$ Culture incorporated fatty-acid-free BSA (FAF-BSA) or serum obtained from ewes offered diets enriched with either n-3 or n-6 PUFA (Wonnacott et al. 2010).

(1998)) as being early, mid, expanding, hatching or hatched (data nor presented). However, the inclusion of either PUFA-enriched serum or albumin, but not LDL, increased $(P<0.001)$ the proportion of lower grade (IETS 1998) Day-7 blastocysts (Fig. 2). Once again, there was no differential effect of PUFA source.

The inclusion of all three PUFA-enriched supplements reduced transcript expression in Day-7 blastocysts for $S C A R B 1$ and $L D L R$ relative to the FAF-BSA control (Fig. 3A-F). This effect was generally greater for $n-3$ than n-6 PUFA-enriched supplements. Relative to FAF-BSA control, the inclusion of serum or albumin, but not LDL, increased $(P \leq 0.05)$ transcript expression for $S O D 1$ (Fig. 3G-I). Differences $(P<0.001)$ in $S C D$ expression between treatments were evident for the serum supplement experiment but not for the other two experiments, where $S C D$ transcript expression for FAF-BSA control blastocysts was reduced in line with that for embryos cultured in the presence of PUFA-enriched LDL and albumin (Fig. 3J-L). Transcripts for FADS1 were not detected in blastocysts, but transcripts for FADS2 were present and their expression was increased in embryos cultured in the presence of n-6 PUFA-enriched serum, relative to the FAF-BSA control, but not by the other supplements (Fig. 3M-O). Transcripts for ELOVL5 were more abundantly expressed in the 'serum experiment' (i.e. both in supplemented and FAF-BSA control blastocysts; Fig. 3P) than in experiments in which the other two supplements were added (Fig. 3Q and R). The inclusion of PUFA-enriched LDL reduced $(P=0.003)$ transcript expression for ELOVL5 relative to FAF-BSA control blastocysts. Neither PUFA-enriched serum nor albumin altered ELOVL5 expression in blastocysts relative to FAF-BSA controls.

\section{Discussion}

Several important and novel findings emerge from these experiments, which add to our previous observations (Wonnacott et al. 2010). It was reported in that study that the increase in follicular fluid $\mathrm{P}_{4}$ concentrations in ewes fed n-3 PUFA compared to n-6 PUFA-enriched diets could not be recapitulated in GCs cultured in the presence of PUFA-enriched HDL. This study confirms this observation and now reveals, for the first time, that the $\mathrm{n}-3$ PUFA-associated increase in $\mathrm{P}_{4}$ levels within the ovarian follicle arises solely in theca cells, and is mediated in part by an n-3 PUFA-associated increase

Table 6 Total fatty acids (TFA) and percentages (g/100 g TFA) of saturated, unsaturated, monounsaturated (MUFA) and polyunsaturated (PUFA) fatty acids of Day-7 sheep blastocysts cultured ${ }^{\mathrm{a}}$ in vitro. Analysis was based on three replicate groups of 10-35 embryos.

\begin{tabular}{|c|c|c|c|c|c|c|c|c|c|c|}
\hline \multirow{2}{*}{$\begin{array}{l}\text { Serum fraction } \\
\text { PUFA source }\end{array}$} & \multirow[b]{2}{*}{ FAF-BSA } & \multicolumn{2}{|c|}{ LDL } & \multicolumn{2}{|c|}{ Albumin (Alb) } & \multirow[b]{2}{*}{ S.E.D. } & \multicolumn{4}{|c|}{ Orthogonal contrasts } \\
\hline & & $n-3$ & $n-6$ & $n-3$ & $n-6$ & & $\begin{array}{c}\text { FAF-BSA } \\
\text { versus suppl }\end{array}$ & $\begin{array}{l}\text { LDL versus } \\
\text { Alb }\end{array}$ & $\begin{array}{l}\text { LDL n-3 versus } \\
\text { LDL n-6 }\end{array}$ & $\begin{array}{l}\text { Alb } n-3 \text { versus } \\
\text { Alb } n-6\end{array}$ \\
\hline$n$ & 3 & 3 & 3 & 3 & 3 & & & & & \\
\hline TFA (ng/blastocyst) & 117.2 & 115.3 & 121.1 & 126.6 & 131.1 & 4.17 & 0.09 & 0.02 & - & - \\
\hline Saturated & 33.0 & 34.2 & 33.2 & 31.0 & 33.4 & 1.34 & - & - & - & - \\
\hline Unsaturated & 63.9 & 61.9 & 63.1 & 65.4 & 62.7 & 1.21 & - & - & - & 0.06 \\
\hline MUFA & 48.9 & 47.5 & 47.9 & 50.2 & 48.9 & 1.52 & - & - & - & - \\
\hline PUFA & 14.3 & 14.4 & 15.2 & 15.2 & 13.9 & 0.95 & - & - & - & - \\
\hline$n-6$ series & 12.9 & 13.3 & 14.4 & 11.6 & 11.6 & 1.01 & - & 0.014 & - & - \\
\hline$n-3$ series & 1.4 & 1.1 & 0.7 & 3.6 & 2.3 & 0.48 & - & 0.001 & - & 0.042 \\
\hline Ratio of n-6:n-3 & 9.8 & 12.2 & 19.8 & 3.3 & 6.8 & 1.32 & - & $<0.001$ & 0.011 & 0.047 \\
\hline
\end{tabular}

${ }^{a}$ Culture incorporated fatty-acid-free BSA (FAF-BSA) or a supplement (suppl) of low-density lipoprotein or albumin fractionated from serum of ewes offered diets enriched with either n-3 or n-6 PUFA (Wonnacott et al. 2010). 


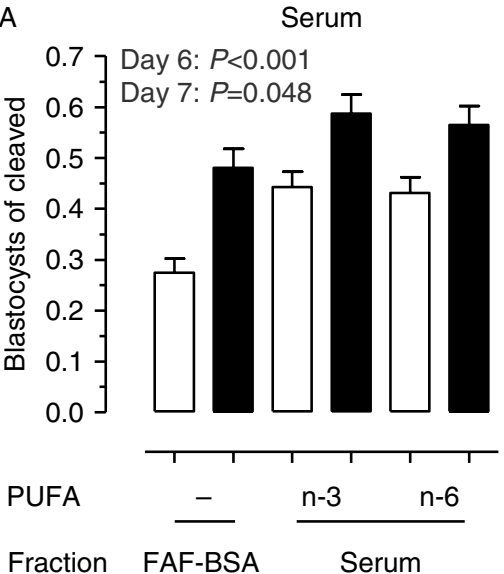

B
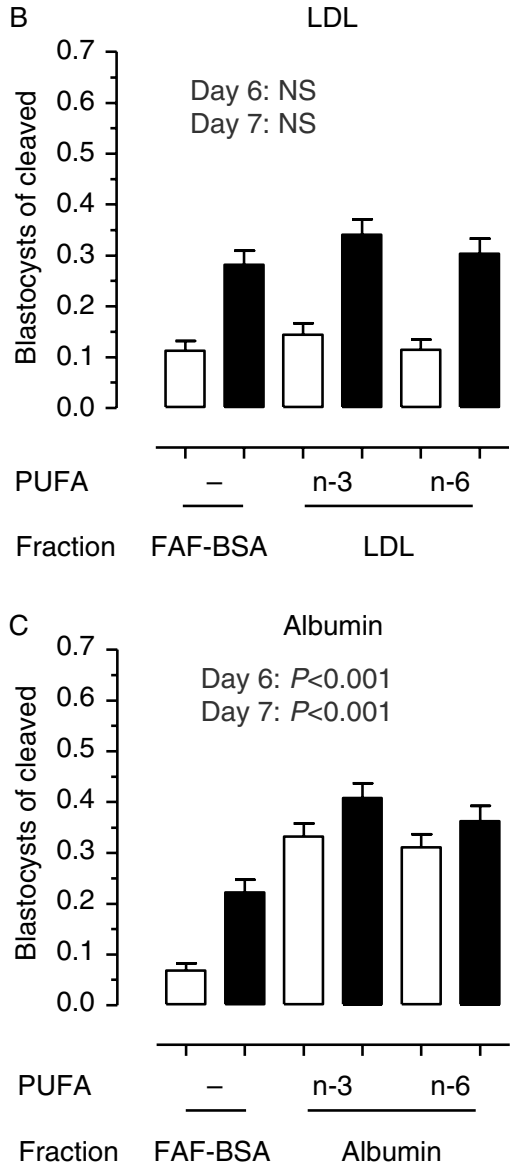

Figure 1 Embryo development following 6 (open bars) or 7 (filled bars) days of culture in synthetic oviductal fluid media supplemented with either fatty-acid-free BSA (FAF-BSA) or one of the three PUFAenriched supplements (A) serum, (B) low-density lipoproteins (LDL) or (C) albumin; the latter two supplements were fractionated from the serum used in (A). This serum was derived from ewes offered either n-3 or $n-6$ polyunsaturated fatty acid (PUFA)-enriched diets. Levels of significance represent orthogonal contrasts between each supplement and FAF-BSA. There was no differential effect of n-3 and n-6 PUFA on embryo development. in STAR transcript expression. Furthermore, delivery of n-3 PUFA from either LDL or HDL, in a manner that supports both theca cell proliferation and steroidogenesis, appears equally efficacious although, by $144 \mathrm{~h}$ culture, only n-3 PUFA-enriched HDL in this study was associated with increased $\mathrm{P}_{4}$ production in partially luteinised theca cells. Although the mechanisms underlying this effect are not clear they are consistent with the observations of Bao et al. (1995), who also found that $\mathrm{HDL}$, but not $\mathrm{LDL}$, increased $\mathrm{P}_{4}$ production in bovine theca cells between 96 and $144 \mathrm{~h}$ culture. Furthermore, this effect may be induced by the underlying protein molecule as Chandras et al. (2004) found that lipid-free apolipoprotein-A1 increased $\mathrm{P}_{4}$ production in human granulosa-lutein cells following 3 days of culture.

The study of Wonnacott et al. (2010) also revealed that there is no net uptake of FA from HDL by sheep embryos, so that FA composition was similar to embryos cultured in the presence of FAF-BSA. This study extends this observation to demonstrate that there is also no net increase in FA content of sheep embryos when cultured in the presence of $L D L$, but that culture in the presence of either PUFA-enriched serum or albumin leads to a net increase in FA content of Day-7 blastocysts. Furthermore, in terms of absolute mass (ng/blastocyst), culture of sheep embryos in the presence of n-3 PUFA-enriched serum or albumin, but not n-3 PUFA-enriched LDL, increased the intra-cellular content of $n-3$ series PUFA. A greater proportion of embryos cultured in the presence of either serum or albumin developed to the blastocyst stage, but more of these were classified as having moderate to poor morphological grades associated with increased transcript expression for the antioxidant enzyme SOD1.

Finally, this study reports for the first time the expression of transcripts for specific enzymes involved in fatty acid elongation and desaturation in the ruminant ovarian follicle and in the mammalian pre-implantation embryo. Transcripts for SCD, FADS1 and FADS2, along with transcripts for ELOVL5, were expressed in the three cell types studied. However, although expressed in sheep liver (data not presented), transcripts for ELOVL2 were not detected in either granulosa or theca cells, or in Day-7 blastocysts. This latter observation is somewhat at odds with an earlier study revealing mRNA expression for ELOVL2 in the mouse testis (Tvrdik et al. 2000), suggesting either species- and/or a gender-specific tissue distribution for this enzyme.

\section{Granulosa and theca cell culture}

Lipoprotein fractions in this study were added to TCM199 and DMEM/Hams-F12 so that FA supply was equivalent to that provided by serum incorporated at $5 \%$ $\mathrm{v} / \mathrm{v}$. Measured concentrations of FA in supplemented media matched predictions (Supplementary Table 5) but, understandably, were considerably lower than those 
found in body fluids including follicular fluid to which granulosa and theca cells are exposed (Sinclair et al. 2008). Under such circumstances, cholesterol provision for steroidogenesis will be limiting so that the provision of lipoprotein fractions in this study and that of Wonnacott et al. (2010), albeit at low levels, enhanced
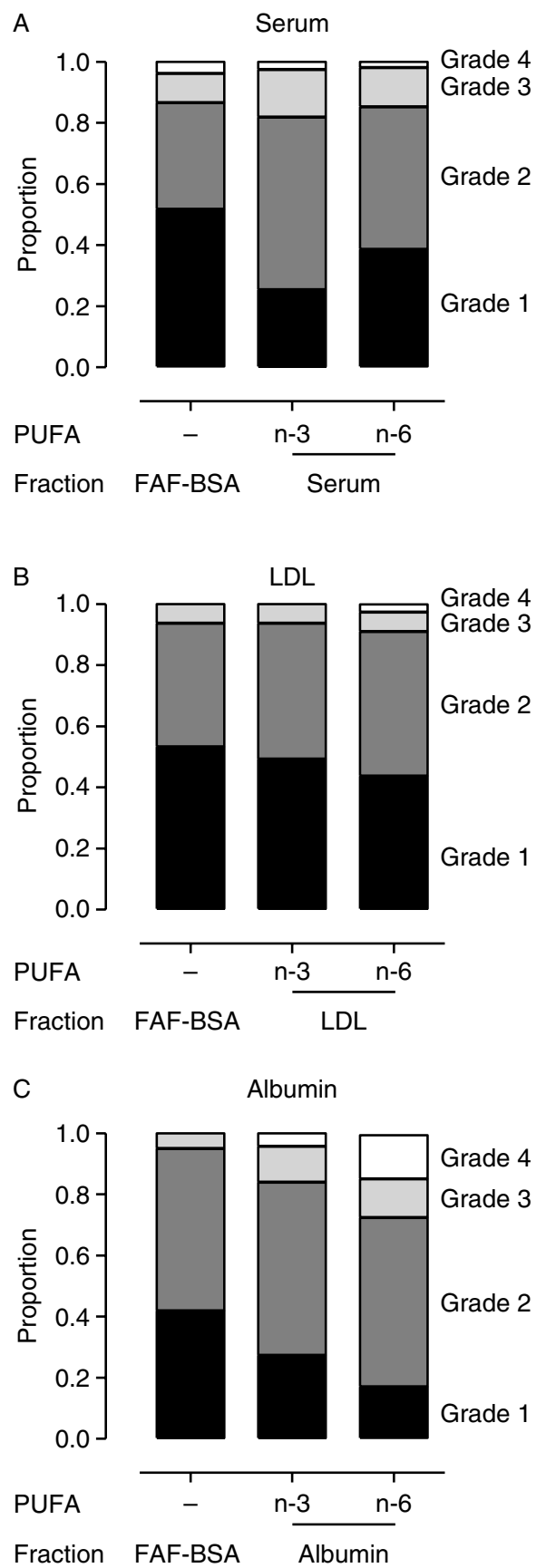

Figure 2 Morphological grade (IETS 1998; Grade 1 is good, Grade 4 is poor) of Day-7 blastocysts cultured in synthetic oviductal fluid media supplemented with either fatty-acid-free BSA (FAF-BSA) or one of the three PUFA-enriched supplements described in Fig. 1. The inclusion of either serum $(A)$ or albumin $(C)$ increased $(P<0.001)$ the proportion of embryos with poor grades. In contrast LDL (B) had no effect on embryo grade.
$\mathrm{P}_{4}$ and $\mathrm{E}_{2}$ production by cultured follicular cells. This is perhaps further exemplified in this study where the provision of $\mathrm{LDL}$, which contains proportionally more cholesterol and cholesteryl esters than HDL (Christie 1981), increased $\mathrm{P}_{4}$ production and STAR expression relative to $\mathrm{HDL}$ in GCs. Consistent with the previous observations of Wonnacott et al. (2010), there was no differential effect of $\mathrm{n}-3$ and $\mathrm{n}-6$ PUFA on $\mathrm{P}_{4}$ production by cultured GCs, which is in stark contrast to that observed for theca cells in this study, where both $n-3$ PUFA-enriched LDL and HDL increased $\mathrm{P}_{4}$ production and STAR transcript expression relative to $\mathrm{n}-6$ PUFAenriched lipoproteins. These observations support the increase in $\mathrm{P}_{4}$ concentrations in follicular fluid reported for ewes offered an n-3 PUFA-enriched diet (Wonnacott et al. 2010). The mechanisms that explain this effect are complex, not fully understood and are beyond the immediate scope of this study to explore in any great depth. A putative stimulatory effect on steroidogenesis by n-3 PUFA, however, could arise as a consequence of their known inhibitory effects on prostaglandinendoperoxide synthase 2 (PTGS2) activity (Ringbom et al. 2001), as inhibition of PTGS2 activity with indomethacin in MA-10 mouse Leydig cells enhanced STAR transcript expression (Wang et al. 2003). Alternatively, or in addition, this increase in STAR expression and $\mathrm{P}_{4}$ production by theca cells may have arisen as a consequence of reduced (to around 50\%) levels of arachidonic acid (C20:4n-6) in n-3 PUFA-supplemented cells. Certain metabolites of arachidonic acid are known to inhibit STAR expression (Wang et al. 2006).

The 7.5-fold increase in $S C D$ transcript expression in GCs is consistent with that reported previously (Wonnacott et al. 2010) for this cell type, and probably represents a feature of cells cultured with relatively high (i.e. $10 \mathrm{ng} / \mathrm{ml}$ ) concentrations of insulin, which is known to increase $S C D$ expression in sheep tissues (Daniel et al. 2004). Both LH and insulin have been reported to increase STAR expression in cultured porcine theca cells (Zhang et al. 2000), and transcript expressions of ELOVL5 and FADS1 are also known to be responsive to insulin (Brenner et al. 2003). In theca cells, the increase in CYP11A, HSD3B1 and STAR over time was consistent with the temporal increase in $\mathrm{P}_{4}$ production. The temporal decrease in CYP17A expression in theca cells, on the other hand, was consistent with the onset of luteinisation in this cell type (Demeter-Arlotto et al. 1993).

\section{Embryo culture}

In contrast to LDL, which had no effect, serum and albumin supplementation of SOFM enhanced blastocyst yields and PUFA-enriched serum and albumin increased the FA content of Day-7 sheep blastocysts. However, this was associated with poorer morphological grades and increased SOD1 transcript expression, indicative of enhanced superoxide toxicity (Lequarré et al. 2001). 
Lipid accumulation by ovine embryos cultured in the presence of serum has been reported previously and this was also associated with markers of impaired embryo quality (Thompson et al. 1995, Reis et al. 2003a, 2005). Lipid peroxidation was also enhanced in Day-3 sheep embryos cultured with FAF-BSA, to which DHA
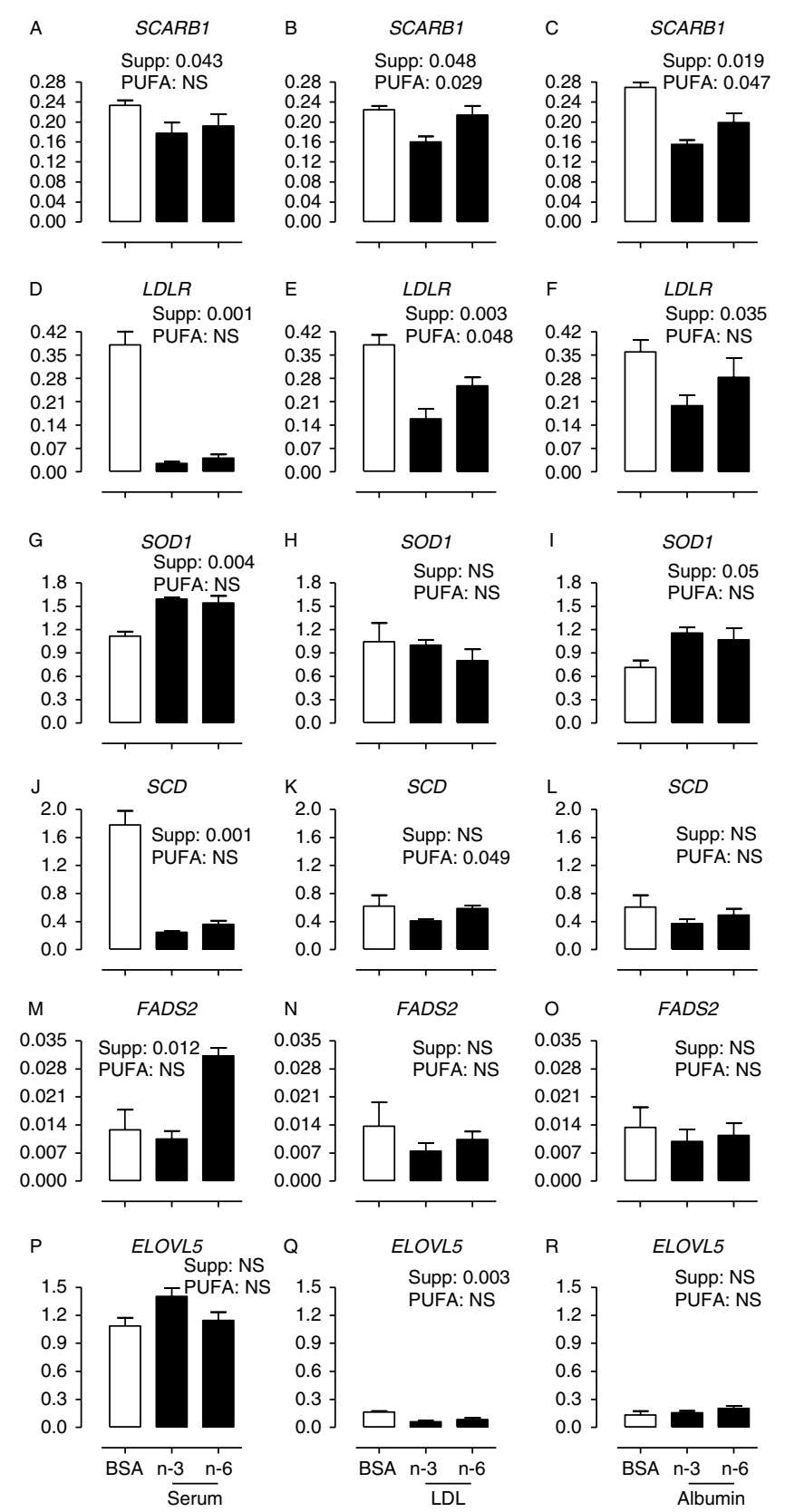

Figure 3 Transcript expression (relative to GAPDH) of Day-7 blastocysts cultured in synthetic oviductal fluid media supplemented with either fatty-acid-free BSA (BSA, open bars) or one of the three PUFA-enriched supplements (filled bars) (serum, left column; LDL, middle column; albumin, right column). Levels of significance are for orthogonal contrasts between (i) each supplement (Supp) and BSA controls and (ii) within $n-3$ versus $n-6$ PUFA-enriched supplements (PUFA); NS, not significant.
(C22:6n-3) was complexed, leading to arrested development at the 8-16-cell stage (Reis et al. 2003b).

Considered together, evidence from this study and that of Wonnacott et al. (2010) demonstrate that preimplantation embryos acquire FA, particularly n-3 PUFA, from the albumin fraction of serum and not from the other major lipoprotein fractions. However, in the absence of a net uptake of $\mathrm{FA}, \mathrm{HDL}$, presumably acting via SCARB1, reduced the transcript expression for $L D L R$ and $S C D$ and, in the case of n-6 PUFA-enriched $\mathrm{HDL}$, reduced the proportion of zygotes that developed to the blastocyst stage (Wonnacott et al. 2010). Despite PUFA compositional differences in this study, however, there was evidence of only a partial effect of PUFA source on transcript expression (e.g. for SCARB1 and $L D L R)$ and no differential effect on embryo development or quality. The increase in FADS2 expression in embryos cultured with n-6 PUFA-enriched serum compared to control and n-3 PUFA-exposed embryos is enigmatic as neither LDL nor albumin-derived PUFAs had any differential effect on expression of transcripts for this gene. It may merely reflect some obscure mechanism associated with the relatively low percentage of linoleic (C18:2n-6) and $\alpha$-linolenic (C18:3n-3) acids in embryos from this experiment.

A notable feature of Day-7 blastocysts in this study was their high FA content (110-170 ng/blastocyst), which was greater than that reported by Wonnacott et al. (2010) (60-80 ng/blastocyst) and Reis et al. (2002) (68-124 ng/ blastocyst). From Table 4, it is apparent that the differences between the current three culture experiments are inherent to the FA composition of oocytes from which these embryos were derived; they are clearly not a feature of the culture conditions per se. Basic SOFM and SOFM+ FAF-BSA had only trace amounts of FA (i.e. 0.0025 that of serum), which are probably contaminants in some of the organic supplements (e.g. amino acids) added. Oocytes used in the current series of experiments were from abattoir-derived ovaries for which we have no information on genotype, age or dietary background of donors. This non-descript background also probably accounts for the reduced blastocyst yields observed in the LDL and albumin experiment (which was conducted between January and March, 2010) compared with the serum experiment (conducted during November and December, 2009). Support for the contention that the differences in FA composition of embryos between experiments are biological rather than analytical in nature are gained, firstly, from the increase in transcript expression for ELOVL5 in the serum experiment relative to either the LDL or albumin experiment, in which PUFA levels were almost twofold higher. Support is also provided by the negative relationship between transcript expression for $S C D$ and the percent oleic (C18:1) and linoleic (C18:2n-6) acid of Day-7 blastocysts cultured in FAF-BSA across the three experiments (Supplementary Figure 1, see section on supplementary data given at the end of this article). 
Diets rich in PUFA are known to reduce $S C D$ transcript expression in mice and recently, using promoter-reporter gene constructs transfected into kidney- and liver-derived cell lines, Zulkifli et al. (2010) demonstrated that the addition of both oleic and linoleic acid to culture media reduced the activity of the $S C D$ promoter from four different species (i.e. human, mouse, pig and sheep) in a dose-dependent manner.

\section{Conclusions}

PUFA act on both granulosa and theca cells within the ovarian follicle to promote steroidoegenesis, but the differential effects of $n-3$ and $n-6$ PUFA on $\mathrm{P}_{4}$ production are mediated solely within theca cells, and this may primarily arise as a consequence of increased STAR expression. Although n-3 PUFA from both LDL and HDL enhance $P_{4}$ production by theca cells, relative to $n-6$ PUFA, only HDL-derived $n-3$ PUFA enhance $\mathrm{P}_{4}$ synthesis by luteinising theca cells. The FA composition of sheep embryos is highly variable, largely as a consequence of inherent differences in the FA composition of oocytes. Both serum and albumin promote blastocyst yields when added to culture, but they each impair embryo quality. Given that there was no net uptake of FA from LDL in this study or from HDL in the study of Wonnacott et al. (2010), and that very low density lipoprotein (VLDL) and chylomicrons account for just $0.2 \%$ (by weight) total lipoprotein lipid in serum (Christie 1981), it would appear that albumin is the primary if not sole fraction of serum responsible for FA uptake by embryos during culture, and is effective in the delivery of $n-3$ PUFA. This study highlights important differential effects of $n-3$ and n-6 PUFA on ovarian steroidogenesis, but differential effects on pre-implantation development are less apparent. Future attention will be directed towards assessing the importance of PUFA assimilated during oocyte growth and maturation, relative to PUFA acquired during pre-implantation development, on embryo viability and pregnancy establishment. Indeed, emerging evidence indicates that PUFA supplementation during oocyte maturation in vitro can influence early embryo development (Marei et al. 2010).

\section{Materials and Methods}

All reagents were obtained from Sigma-Aldrich unless otherwise stated.

\section{Fractionation of lipoproteins from serum}

Very low-density $(d=<1.006 \mathrm{~g} / \mathrm{ml})$, low-density $(d=1.006-$ $1.06 \mathrm{~g} / \mathrm{ml})$ and high-density $(d=1.06-1.24 \mathrm{~g} / \mathrm{ml})$ lipoprotein fractions were separated from pooled sera, obtained from ewes offered n-3 and n-6 PUFA-enriched diets, by sequential preparative ultracentrifugation in a Beckman XL-70 Preparative Centrifuge (Beckman Coulter UK Ltd, Buckinghamshire, UK) as described previously (Wonnacott et al. 2010). The remaining fraction was free of lipoproteins and contained mainly albumin. Following dialysis to remove $\mathrm{KBr}$, fractionated lipoproteins and albumin were aliquoted and frozen at $-20^{\circ} \mathrm{C}$ until analysis by gas chromatography or added to culture media of follicular cells or embryos.

\section{Culture of primary granulosa and theca cells}

Granulosa and theca cell experiments were conducted separately, each as a $2 \times 2 \times 3$ factorial (i.e. $\mathrm{LDL}$ versus $\mathrm{HDL}$; $\mathrm{n}-3$ versus $\mathrm{n}-6$ PUFA; and three sample times (48, 96 and $144 \mathrm{~h}$ )) arrangement in $6 \times 24$-well plates (Nunc, Thermo Fisher Scientific, Loughborough, UK). Cells within plate and within treatment combination were harvested from separate wells at 48, 96 and $144 \mathrm{~h}$ for FA and transcript analyses, and spent culture media was analysed for steroid hormones.

Large $(>5 \mathrm{~mm})$ amber-coloured clear follicles were dissected from abattoir-derived sheep ovaries, and GCs were scraped from inner follicle wall using a sterile inoculation loop and oocytes were removed. Theca cells were removed by pinching the inner wall with curved forceps and peeling away from the outer shell. GCs were resuspended in a culture medium (90\% v/v TCM199 and 10\% v/v double distilled water) supplemented with $1 \mathrm{mg} / \mathrm{ml}$ BSA, $100 \mathrm{ng} / \mathrm{ml}$ L-glutamine, $10 \mathrm{ng} / \mathrm{ml}$ insulin, $0.5 \mu \mathrm{g} / \mathrm{ml}$ transferrin, $0.5 \mathrm{ng} / \mathrm{ml}$ sodium selenite, $50 \mathrm{IU} / \mathrm{ml}$ penicillin, $50 \mu \mathrm{g} / \mathrm{ml}$ streptomycin, $1 \mathrm{ng} / \mathrm{ml}$ $\mathrm{FSH}$ and $100 \mathrm{ng} / \mathrm{ml}$ testosterone, at an initial seeding density of $3.5 \times 10^{5}$ viable cells (determined by Trypan blue exclusion) $/ 500 \mu \mathrm{l}$. Theca cells underwent protease digestion in DMEM/Hams F12 media supplemented with $50 \mathrm{IU} / \mathrm{ml}$ penicillin, $50 \mu \mathrm{g} / \mathrm{ml}$ streptomycin, $5 \mathrm{mg} / \mathrm{ml}$ collagenase I, $1 \mathrm{mg} / \mathrm{ml}$ hyaluronidase and $25 \mathrm{~g} / \mathrm{ml}(188 \mathrm{U} / \mathrm{ml})$ DNase1. Cells were incubated at $37^{\circ} \mathrm{C}$ for $30 \mathrm{~min}$, washed and then resuspended in a culture medium (DMEM/Hams F12) supplemented with $1 \mathrm{mg} / \mathrm{ml} \mathrm{BSA}, 100 \mathrm{ng} / \mathrm{ml}$ L-glutamine, $10 \mathrm{ng} / \mathrm{ml}$ insulin, $0.5 \mu \mathrm{g} / \mathrm{ml}$ transferrin, $0.5 \mathrm{ng} / \mathrm{ml}$ sodium selenite, $50 \mathrm{IU} / \mathrm{ml}$ penicillin, $50 \mu \mathrm{g} / \mathrm{ml}$ streptomycin, $1 \mathrm{ng} / \mathrm{ml} \mathrm{LH}$, at an initial seeding density of $2.0 \times 10^{5}$ viable cells $/ 500 \mu \mathrm{l}$. Plates used for theca cultures were pre-coated with fibronectin $(500 \mu \mathrm{l}$ of $6 \mu \mathrm{g} / \mathrm{ml}$ fibronectin/well at $39^{\circ} \mathrm{C}$ for $4 \mathrm{~h}$, removed then air dried for $2 \mathrm{~h}$ ). Basal media for both cell types was supplemented with lipoproteins at $57 \mu \mathrm{l} / \mathrm{ml}$ media (LDL fraction) and $22 \mu \mathrm{l} / \mathrm{ml}$ media (HDL fraction). These inclusion rates were calculated to provide FA at level equivalent to that of $5 \% \mathrm{v} / \mathrm{v}$ serum (Table 1 ). Both media were kept at $\mathrm{pH} 7.4$ and 270-280 mOsm and cells were incubated at $38.8{ }^{\circ} \mathrm{C}$ in a humidified atmosphere of $5 \%$ $\mathrm{CO}_{2}$ for up to $144 \mathrm{~h}$. Eighty percent of the media was collected at $48 \mathrm{~h}$ intervals, and replaced with fresh media. All cells were snap-frozen in liquid nitrogen prior to storage at $-80^{\circ} \mathrm{C}$.

\section{Embryo culture}

The culture of sheep zygotes was based on in-house protocols described previously (Powell et al. 2006, Wonnacott et al. 2010), and only a brief summary is provided here. Grades 1 and 2 cumulus-oocyte complexes (COCs) were matured in groups of 50 in $500 \mu \mathrm{l}$ bicarbonated-buffered TCM199 with supplements. For fertilisation, $1 \times 10^{6}$ motile spermatozoa from a 
single ram was added $/ \mathrm{ml}$ of media containing matured oocytes (up to $60 /$ well) and incubated for $22 \mathrm{~h}$ at $38.8^{\circ} \mathrm{C}$ in a humidified atmosphere of $5 \% \mathrm{CO}_{2}$ in air. Over the course of three experiments, zygotes (four to eight cells) were selected and cultured in groups of $30-50$ in $400 \mu$ SOFM (Supplementary Table 5) to which various supplements were added. Experiment 1 : i) $0.1 \% \mathrm{w} / \mathrm{v}$ FAF-BSA (control), ii) n-3 PUFAenriched serum (5\% v/v) or iii) n-6 PUFA-enriched serum $(5 \%$ v/v). Experiment 2: i) $0.1 \% \mathrm{w} / \mathrm{v}$ fFAF-BSA (control), ii) $11 \mu \mathrm{ln}-3$ PUFA-enriched LDL/ml media or iii) $11 \mu \mathrm{ln}-6$ PUFA-enriched $\mathrm{LDL} / \mathrm{ml}$ media. Experiment 3: i) $0.1 \% \mathrm{w} / \mathrm{v}$ FAF-BSA (control), ii) $160 \mu \mathrm{ln}-3$ PUFA-enriched albumin/ml media or iii) $160 \mu \mathrm{l}$ $\mathrm{n}-6$ PUFA-enriched albumin/ml media. The inclusion rates for LDL and albumin were calculated to provide FA at level equivalent to that of $1 \% \mathrm{v} / \mathrm{v}$ serum (Table 1 ). The serum experiment was replicated 8 times, whereas the LDL and albumin experiments were replicated 10 and 11 times respectively. Embryo quality (i.e. stage of development and grade) was assessed on Days 6 and 7 of culture according to the International Embryo Transfer Society (IETS) classification system (IETS 1998). Day-7 embryos within well were washed in $1 \times \mathrm{PBS}$ and $0.1 \%$ polyvinyl alcohol (PVA), snap-frozen in minimal volume and stored at $-80{ }^{\circ} \mathrm{C}$ until either $\mathrm{FA}$ or transcript analysis.

\section{Fatty acid analysis}

Fatty acid analyses of culture media, serum and lipoprotein fractions (i.e. LDL, HDL and albumin), GCs, theca cells and blastocysts were based on established in-house protocols (Fouladi-Nashta et al. 2009, Wonnacott et al. 2010). Twentysix quantitatively significant and/or biologically important fatty acids were identified for subsequent statistical analysis. Blastocyst FA were extracted from pools of 10-35 embryos, together with $50 \mu \mathrm{l}$ of $100 \mu \mathrm{g} / \mathrm{ml}$ internal standard (pentadecanoic acid; C15:0), using a 2:1 mixture of

Table 7 Alphabetical list of primer and probe sequences used for real-time quantitative PCR analysis of transcript expression in follicular cells and embryos.

\begin{tabular}{|c|c|c|c|}
\hline Name & Name & Sequence $5^{\prime}-3^{\prime}$ & NCBI accession numbers \\
\hline \multirow[t]{3}{*}{$A C T B$} & $\mathrm{~F}$ & TGTGCGTGACATCAAGGAGAA & AF129289 \\
\hline & $\mathrm{R}$ & CGCAGTGGCCATCTCСTG & Ovis aries \\
\hline & Probe & FAM-CTGCTACGTGGCCCTGGACTTCGA-TAMRA & \\
\hline \multirow{3}{*}{ CYP11A1 } & $\mathrm{F}$ & TCGGCAATTTGGAGTCAGTTT & D50057 \\
\hline & $\mathrm{R}$ & GGTAGGATCCСTCGAACTTAAAGAG & Ovis aries \\
\hline & Probe & FAM-ATCATTCACCСTGAAGGCGTGGCC-TAMRA & \\
\hline \multirow[t]{3}{*}{ CYP17A } & $\mathrm{F}$ & TCATCTCGCCATCGTTAAGCT & AF251388 \\
\hline & $\mathrm{R}$ & CGGGCTAGCATCTCACCTACA & Ovis aries \\
\hline & Probe & FAM-TTGCCCTTTGGAGCCGGACCC-TAMRA & \\
\hline \multirow[t]{3}{*}{ ELOVL2 } & $\mathrm{F}$ & TTCCTTGTGGGCAAAGTTTCTT & BC114786 \\
\hline & $\mathrm{R}$ & GCCCGTAGTAGGAGTACATGAGGAT & Bos taurus \\
\hline & Probe & FAM-ACGTCTACСАССАСGССТССАTGTTT-TAMRA & \\
\hline \multirow{3}{*}{ ELOVL5 } & $\mathrm{F}$ & TCACGGTCCTGCATGTGTATC & BC105391 \\
\hline & $\mathrm{R}$ & GACCCAGTTCATCACGAACCA & Bos taurus \\
\hline & Probe & FAM-CCACGCCAGCATGCTCAACATCTG-TAMRA & \\
\hline \multirow[t]{3}{*}{ FADS1 } & $\mathrm{F}$ & AGCTGCCCCTGAGGATATTTC & EU272818 \\
\hline & $\mathrm{R}$ & CGACCACTCGAAGATGTCGTT & Ovis aries \\
\hline & Probe & FAM-CTGCTGCСАACTCCATGGCTTTCC-TAMRA & \\
\hline \multirow[t]{3}{*}{ FADS2 } & $\mathrm{F}$ & TGGCCTGCATGCTCATCA & BC133520 \\
\hline & $\mathrm{R}$ & TGGAAGATGTTGACGTGGAGAT & Bos taurus \\
\hline & Probe & FAM-AGGTCCCTGCTGGCCCACCC-TAMRA & \\
\hline \multirow[t]{3}{*}{ GAPDH } & $\mathrm{F}$ & TCCGTTGTGGATCTGACCTG & AF030943 \\
\hline & $\mathrm{R}$ & TGCTTCACСАCСТTCTTGATCTC & Ovis aries \\
\hline & Probe & FAM-CGCCTGGAGAAACCTGCCAAGTATGA-TAMRA & \\
\hline \multirow[t]{3}{*}{$H S D 3 B 1$} & $\mathrm{~F}$ & CCAGGCTAGTGTGCCAGTCTTT & NM_001135932 \\
\hline & $\mathrm{R}$ & CTCCCTGTAGGCGTTGGGCC & Ovis aries \\
\hline & Probe & FAM-TCCACACCAGCACCATAGAGGTGGCT-TAMRA & \\
\hline \multirow[t]{3}{*}{$L D L R$} & $\mathrm{~F}$ & GAGCGTGGGTGCCCTATACA & K01830 \\
\hline & $\mathrm{R}$ & TTCCGAAGGCCAGGAGG & Bos taurus \\
\hline & Probe & FAM-СGTССТССССАТСGСАСТGСТС-TAMRA & \\
\hline \multirow[t]{3}{*}{ SCARB1 } & $\mathrm{F}$ & TCCAAGGCCAGAAGCCAC & AF019384 \\
\hline & $\mathrm{R}$ & GСТCTTGTGССТGAАСТССС & Bos taurus \\
\hline & Probe & FAM-TGCAGGAGCACGGGCCTTATGTGTA-TAMRA & \\
\hline \multirow[t]{3}{*}{$S C D$} & $\mathrm{~F}$ & CGAACCTACAAAGCTCGGCT & NM_001009254 \\
\hline & $\mathrm{R}$ & TGGAACGCCATGGTGTTG & Ovis aries \\
\hline & Probe & FAM-CCССTACGGGTCTTCCTGATCATCG-TAMRA & \\
\hline \multirow[t]{3}{*}{ SOD1 } & $\mathrm{F}$ & GCCGTCTGCGTGCTGAA & XM 584414 \\
\hline & $\mathrm{R}$ & АCTGTATTTCCCTTTGCCTCGA & Bos taurus \\
\hline & Probe & FAM-CCCGGTGCAAGGCACCATCC-TAMRA & \\
\hline \multirow[t]{3}{*}{ STAR } & $\mathrm{F}$ & GCGACGTTTAAGCTGTGTGCT & AF290202 \\
\hline & $\mathrm{R}$ & TGCTGCCGCAGCCC & Ovis aries \\
\hline & Probe & FAM-AGCTCCTATAGACACGTGCGCAGCATG-TAMRA & \\
\hline
\end{tabular}


chloroform:methanol and methylated using methanolic $\mathrm{HCl}$ using the same protocol as described for GCs (Fouladi-Nashta et al. 2009). A dedicated Varian CP-Sil 88-fused silica capillary column $(100 \mathrm{~m} \times 0.25 \mathrm{~mm}$ ID, $0.2 \mu \mathrm{m}$ film) was used to analyse blastocysts (Wonnacott et al. 2010) as the quantities of fatty acid methyl esters were so low.

\section{Steroid analysis}

Culture media $E_{2}$ (diluted 1:10 for GCs) were analysed in duplicate by an in-house ELISA; 96-well plates (ImmunoMaxisorp; Nuncbrand Fisher Scientific) were coated with $E_{2} 3$ antibody (Abcam, Cambridge, UK) at a dilution of 1:64 000 in coating buffer (50 mM sodium bicarbonate, $50 \mathrm{mM}$ sodium carbonate, $\mathrm{pH}$ 9.6), sealed and incubated overnight at $4{ }^{\circ} \mathrm{C}$. Plates were washed four times in wash buffer (PBS, 0.05\% Tween20, pH 7.4) and $100 \mu$ l blocking solution (PBS, 3\% BSA) added to each well and incubated at room temperature for $2 \mathrm{~h}$. Following washing, $100 \mu$ l of either sample, standard or QC, was added to each well together with $100 \mu \mathrm{l} \mathrm{HRP-conjugate}$ and incubated for $2 \mathrm{~h}$ at room temperature. Plates were washed again and $50 \mu$ tetramethylbenzidine were added to each well and incubated for $12 \mathrm{~min}$ at room temperature; $50 \mu \mathrm{l}$ stop solution $\left(0.5 \mathrm{M} \mathrm{H}_{2} \mathrm{SO}_{4}\right)$ were added to each well and plates were read at $450 \mathrm{~nm}$. The limit of detection was $39 \mathrm{pg} / \mathrm{ml}$, and the working range extended to $10 \mathrm{ng} / \mathrm{ml}$. Intra- and inter-assay coefficient of variation (CV) values were 9.8 and $4.2 \%$ respectively. $\mathrm{P}_{4}$ ELISA was carried out on spent media as previously described (Wonnacott et al. 2010). Samples were diluted up to 1:400 (for theca cells) and up to 1:100 (for GCs). Intra- and inter-assay CV values were 7.9 and $8.4 \%$ respectively.

\section{Transcript analysis}

Total RNA was extracted from cultured ovine granulosa and theca cells using RNeasy Mini kit, followed by RNase-free DNase (Promega) to remove genomic DNA contamination, and reverse transcribed using Omniscript RT kit (Qiagen Ltd; Kanakkaparambil et al. 2009, Wonnacott et al. 2010). RNA was extracted from pools of 10 to 35 ovine blastocysts using Dynabeads mRNA DIRECT kit (Invitrogen Ltd; Kwong et al. 2006). RT of mRNA from blastocysts was performed using QuantiTect RT kit (Qiagen Ltd), which eliminates genomic DNA and efficiently reverse transcribes small quantities of RNA in a two-step reaction. To ensure no genomic DNA contamination in samples, - RT (equivalent to 0.7 blastocyst) was used in quantitative RT-PCR (qRT-PCR) with ACTB qRT-PCR. qRTPCR was performed using Roche LightCycler 480 (Roche Diagnostics Ltd) with gene-specific primers and TaqMan probes (Table 7). For blastocysts, cDNA equivalent to 0.7 embryo was added to each PCR. The probes and primers for qRT-PCR were designed using Primer Express. All TaqMan probes were labelled with $6^{\prime}$-carboxyfluorescin (FAM) and $6^{\prime}$-carboxy- $N, N, N^{\prime}, N^{\prime}$-tetramethylrhodamine (TAMRA) at $5^{\prime}$ and $3^{\prime}$ end respectively (Eurofins MWG Operon, Raynes Park, London, UK). For each target gene, sequence homology was matched to the ovine sequence but where this was not possible the bovine sequence was used. The size of PCR product was confirmed by gel electrophoresis.

\section{Statistical analysis}

All statistical analyses were conducted using Genstat release 11.1 (Genstat 2008). FA and steroid concentrations in media and cells were analysed by using ANOVA. $\mathrm{P}_{4}$ data were transformed $\left(\log _{10}\right)$ prior to analysis to satisfy the condition of 'additivity', i.e. to correct for the differences in means and variance across the three time points. Data are presented as geometric means with $\log _{10}$ means and S.E.D. presented in italics. Where an FA was not detectable in a single treatment (i.e. an FA percentage $<0.03$ g/100 g TFA), then the FA percentage in the other treatment was analysed by using a two-tailed t-test to determine whether it was significantly greater than the detection limit. In the case of cultured granulosa and theca cells, data were analysed by ANOVA as a three-way factorial randomised block design as described earlier.

The proportions of zygotes that developed into blastocysts were analysed by analysis of deviance using generalised linear models assuming binomial errors and with logit link functions. Data are presented as predicted back-transformed means \pm S.E.M. Transcript and FA data for blastocysts were analysed by ANOVA. For FA analysis of embryos in the serum experiment, and in the analysis of transcript expression for each of the three supplements, the variations associated with two degrees of freedom related to the three treatment groups were, in each case, partitioned into two orthogonal linear contrasts (i.e. FAF-BSA versus supplement (i.e. serum, LDL or albumin) and $n-3$ supplement versus $n-6$ supplement). For the embryo culture experiment that assessed the effects of $n-3$ and n-6 PUFA-enriched LDL and albumin on the fatty acid composition of embryos, the variations associated with four degrees of freedom related to the five treatment groups were partitioned into the following orthogonal contrasts (FAF-BSA versus supplement, LDL versus albumin, $n-3$ PUFA LDL versus $n-6$ PUFA LDL and $n-3$ albumin versus $n-6$ albumin).

Finally, the effects of culture treatment and morphological assessments of embryo stage on embryo grade were assessed by ordinal regression analysis assuming multinomial errors with logit link functions. Data are presented as the proportion of embryos within each of the four embryo-grade categories.

\section{Supplementary data}

This is linked to the online version of the paper at http://dx.doi. org/10.1530/REP-10-0337.

\section{Declaration of interest}

The authors declare that there is no conflict of interest that could be perceived as prejudicing the impartiality of the research reported. 


\section{Funding}

This work was supported by the University of Nottingham, and J Hughes was supported by an Interdisciplinary Doctoral Training Centre award, University of Nottingham.

\section{Acknowledgements}

The authors acknowledge the independent statistical advice offered by Dr Jim Craigon, University of Nottingham.

\section{References}

Adamiak SJ, Powell K, Rooke JA, Webb R \& Sinclair KD 2006 Body composition, dietary carbohydrates and fatty acids determine postfertilisation development of bovine oocytes in vitro. Reproduction 131 247-258. (doi:10.1530/rep.1.00871)

Bao B, Thomas MG, Griffith MK, Burghardt RC \& Williams GL 1995 Steroidogenic activity, insulin-like growth factor-I production, and proliferation of granulosa and theca cells obtained from dominant preovulatory and nonovulatory follicles during the bovine estrous cycle: effects of low-density and high-density lipoproteins. Biology of Reproduction 53 1271-1279. (doi:10.1095/biolreprod53.6.1271)

Brenner RR, Rimoldi OJ, Lombardo YB, Gonzalez MS, Bernasconi AM, Chicco A \& Basabe JC 2003 Desaturase activities in rat model of insulin resistance induced by a sucrose-rich diet. Lipids 38 733-742. (doi:10. 1007/s11745-003-1121-x)

Chandras C, Ragoobir J, Barret GE, Bruckdorfer KR, Graham A, Abayasekara RE \& Michael AE 2004 Roles for prostaglandins in the steroidogeneic response of human granulosa cells to high-density lipoproteins. Molecular and Cellular Endocrinology 222 1-8. (doi:10. 1016/j.mce.2004.05.008)

Childs S, Hennessy AA, Sreenan JM, Wathes DC, Cheng Z, Stanton C, Diskin MG \& Kenny DA 2008 Effect of level of dietary n-3 polyunsaturated fatty acid supplementation on systemic and tissue fatty acid concentrations and on selected reproductive variables in cattle. Theriogenology 70 595-611. (doi:10.1016/j.theriogenology.2008. 04.002)

Christie WW 1981 The composition, structure and function of lipids in the tissues of ruminant animals. In Lipid Metabolism in Ruminant Animals, pp 95-191. Ed. WW Christie. Oxford, NY: Pergamon Press.

Daniel ZC, Richards SE, Salter AM \& Buttery PJ 2004 Insulin and dexamethasone regulate stearoyl-CoA desaturase mRNA levels and fatty acid synthesis in ovine adipose tissue explants. Journal of Animal Science 82 231-237.

Demeter-Arlotto M, Rainey WE \& Simpson ER 1993 Maintenance and regulation of $17 \alpha$-hydroxylase expression by bovine thecal cells in primary culture. Endocrinology 132 1353-1358. (doi:10.1210/en.132.3. 1353)

Fouladi-Nashta AA, Wonnacott KE, Gutierrez CG, Gong JG, Sinclair KD, Garnsworthy PC \& Webb R 2009 Oocyte quality in lactating dairy cows fed on high levels of n-3 and n-6 fatty acids. Reproduction 138 771-781. (doi:10.1530/REP-08-0391)

Genstat 2008 Genstat. Release 11.1 Reference Manual. Oxford, UK: Claredon Press, Oxford Science Publications.

Guillou H, Zadravec D, Martin PG \& Jacobsson A 2010 The key roles of elongases and desaturases in mammalian fatty acid metabolism: insights from transgenic mice. Progress in Lipid Research 49 186-199. (doi:10. 1016/j.plipres.2009.12.002)

IETS 1998 Manual of the International Embryo Transfer Society. Eds DA Stringfellow \& SM Seidel. Savoy, IL: International Embryo Transfer Society.

Jenkins TC 1994 Regulation of lipid metabolism in the rumen. Journal of Nutrition 124 1372S-1376S.

Kanakkaparambil R, Singh R, Li D, Webb R \& Sinclair KD 2009 B-vitamin and homocysteine status determines ovarian response to gonadotropin treatment in sheep. Biology of Reproduction 80 743-752. (doi:10.1095/ biolreprod.108.072074)
Kwong WY, Miller DJ, Ursell E, Wild AE, Wilkins AP, Osmond C, Anthony FW \& Fleming TP 2006 Imprinted gene expression in the rat embryo-fetal axis is altered in response to periconceptional maternal low protein diet. Reproduction 132 265-277. (doi:10.1530/rep.1.01038)

Lequarré AS, Feugang JM, Malhomme O, Donnay I, Massip A, Dessy F \& van Langendonckt A 2001 Expression of $\mathrm{Cu} / \mathrm{Zn}$ and $\mathrm{Mn}$ superoxide dismutase during bovine embryo development: influence of in vitro culture. Molecular Reproduction and Development 58 45-53. (doi:10. 1002/1098-2795(200101)58:1 < 45::AID-MRD7 > 3.0.CO;2-J)

Marei WF, Wathes DC \& Fouladi-Nashta AA 2010 Impact of linoleic acid on bovine oocyte maturation and embryo development. Reproduction 139 979-988. (doi:10.1530/REP-09-0503)

Moon YA, Hammer RE \& Horton JD 2009 Deletion of ELOVL5 leads to fatty liver through activation of SREBP-1c in mice. Journal of Lipid Research 50 412-423. (doi:10.1194/jlr.M800383-JLR200)

Powell K, Rooke JA, McEvoy TG, Ashworth CJ, Robinson JJ, Wilmut I, Young LE \& Sinclair KD 2006 Zygote donor nitrogen metabolism and in vitro embryo culture perturbs in utero development and IGF2R expression in ovine fetal tissues. Theriogenology 66 1901-1912. (doi:10. 1016/j.theriogenology.2006.05.008)

Reis A, Mitchell LM, Rooke JA, Ewen M, Lomax MA, Robinson JJ \& McEvoy TG 2002 Fatty acid profiles during development of sheep eggs in vivo. Theriogenology 57 361-793. Abstract 507. (doi:10.1016/S0093691X(01)00676-8)

Reis A, Rooke JA, McCallum GJ, Staines ME, Ewen M, Lomax MA \& McEvoy TG 2003a Consequences of exposure to serum, with or without vitamin $\mathrm{E}$ supplementation, in terms of the fatty acid content and viability of bovine blastocysts produced in vitro. Reproduction, Fertility, and Development 15 275-284. (doi:10.1071/RD03004)

Reis A, Rooke JA, McCallum GJ, Ewen M, Lomax MA \& McEvoy TG 2003b Stress-associated developmental arrest following in vitro ovine embryo culture in the presence of docosahexaenoic acid (DHA). Reproduction. Abstract Series 30 57-58.

Reis A, McCallum GJ \& McEvoy TG 2005 Accumulation and distribution of neutral lipid droplets is non-uniform in ovine blastocysts produced in vitro in either the presence or absence of serum. Reproduction, Fertility, and Development 17 815-823. (doi:10.1071/ RD05017)

Ringbom T, Huss U, Stenholm A, Flock S, Skattebol L, Perera P \& Bohlin L 2001 Cox-2 inhibitory effects of naturally occurring and modified fatty acids. Journal of Natural Products 64 745-749. (doi:10.1021/ np000620d)

Santos JEP, Bilby TR, Thatcher WW, Staples CR \& Silvestre FT 2008 Long chain fatty acids of diet as factors influencing reproduction in cattle. Reproduction in Domestic Animals 43 (Suppl 2) 23-30. (doi:10.1111/j. 1439-0531.2008.01139.x)

Sinclair KD, Lunn LA, Kwong WY, Wonnacott K, Linforth RS \& Craigon J 2008 Amino acid and fatty acid composition of follicular fluid as predictors of in vitro embryo development. Reproductive Biomedicine Online 16 859-868. (doi:10.1016/S1472-6483(10)60153-8)

Stoffel W, Holz B, Jenke B, Binczek E, Gunter RH, Kiss C, Karakesisoglou I, Thevis M, Weber AA, Arnhold $S$ et al. 2008 b6-desaturase (FADS2) deficiency unveils the role of omega3- and omega6-polyunsaturated fatty acids. EMBO Journal 27 2281-2292. (doi:10.1038/emboj.2008. 156)

Thompson JG, Gardner DK, Pugh PA, McMillan WH \& Tervit HR 1995 Lamb birth weight is affected by culture system utilized during in vitro pre-elongation development of ovine embryos. Biology of Reproduction 53 1385-1391. (doi:10.1095/biolreprod53.6.1385)

Tvrdik P, Westerberg R, Silve S, Asadi A, Jakobsson A, Cannon B, Loison G \& Jacobsson A 2000 Role of a new mammalian gene family in the biosynthesis of very long chain fatty acids and sphingolipids. Journal of Cell Biology 149 707-718. (doi:10.1083/jcb.149.3.707)

Wang X, Dyson MT, Jo Y \& Stocco DM 2003 Inhibition of cyclooxygenase-2 activity enhances steroidogenesis and steroidogenic acute regulatory gene expression in MA-10 mouse Leydig cells. Endocrinology 144 3368-3375. (doi:10.1210/en.2002-0081)

Wang Y, Botolin D, Christian B, Busik J, Xu J \& Jump DB 2005 Tissuespecific, nutritional, and developmental regulation of rat fatty acid elongases. Journal of Lipid Research 46 706-715. (doi:10.1194/jlr. M400335-JLR200) 
Wang X, Shen CL, Dyson MT, Yin X, Schiffer RB, Grammas P \& Stocco DM 2006 The involvement of epoxygenase metabolites of arachidonic acid in cAMP-stimulated steroidogenesis and steroidogenic acute regulatory protein gene expression. Journal of Endocrinology 190 871-878. (doi:10. 1677/joe.1.06933)

Wathes DC, Abayasekara DR \& Aitken RJ 2007 Polyunsaturated fatty acids in male and female reproduction. Biology of Reproduction 77 190-201. (doi:10.1095/biolreprod.107.060558)

Wonnacott KE, Kwong WY, Hughes J, Salter AM, Lea RG, Garnsworthy PC \& Sinclair KD 2010 Dietary omega-3 and -6 polyunsaturated fatty acids affect the composition and development of sheep granulosa cells, oocytes and embryos. Reproduction 139 57-69. (doi:10.1530/REP-09-0219)

Zhang G, Garmey JC \& Veldhuis JD 2000 Interactive stimulation by luteinizing hormone and insulin of the steroidogenic acute regulatory
(StAR) protein and $17 \alpha$-hydroxylase/17,20-lyase (CYP17) genes in porcine theca cells. Endocrinology 141 2735-2742. (doi:10.1210/en. 141.8.2735)

Zulkifli RM, Parr T, Salter AM \& Brameld JM 2010 Regulation of ovine and porcine stearoyl coenzyme A desaturase gene promoters by fatty acids and sterols. Journal of Animal Science 88 2565-2575. (doi:10.2527/jas. 2009-2603)

Received 4 August 2010

First decision 13 September 2010

Accepted 2 November 2010 